\section{脱水シート利用冷凍マイワシ調理品の 官能評価}

保井明子, 藤本健四郎*

Effects of Contact-Dehydration Sheets on Sensory Scores of Cooked Frozen Sardine

Akiko Yasui and Kenshiro Fujimoto*

Sendai Shirayuri Junior College, 6-1 Hondencho, Izumi-ku, Sendai 981-3107, Japan

* Graduate School of Agricultural Science, Tohoku University, 1-1 Tsutsumidori-Amamiyamachi, Aoba-ku, Sendai 981-8555, Japan

To assess the protective effect of contactdehydrating sheets on frozen fish, sardine was wrapped with contact-dehydration sheets or polyethylene sheets (control) and frozen up to four weeks in a freezer at $-20^{\circ} \mathrm{C}$. Sensory tests of all cooked frozen sardine, such as grilled, boiled, pan-fried and deep fat-fried showed a significant preference to the dehydrating sheet-wrapped fish over the control. The effects on the grilled and boiled fish were especially remarkable.

(Received Jan. 5, 2002 ; Accepted Apr. 21, 2002)

食品を冷凍保存する際, 氷晶による組織破壊が進むと 解凍時に大量のドリップが生成し, 生鮮食品の場合には 酵素の組織内への漏出による各種の反応が速やかに進行 する. さらに脂質過酸化促進物質が存在する場合には, 脂質過酸化が起こり，異峊が発生して，風味は低下する. 半透膜（ポリビニールアルコール）の間に高濃度の糖 溶液を封入した脱水シート ${ }^{1)}$ は食品の表層から軽度に脱 水するのに有効であり, レバーなどの畜産品の冷凍時に 使用すると, 調理後の総合的な官能評価で食味改善効果 があることを報告した ${ }^{2)}$ 魚類は畜肉と比較して不安定 な高度不飽和脂肪酸に富み, 皮には多くの種類で脂質過 酸化活性があり3)，とくにマイワシではリポキシゲナー ゼが存在する゙)。このため，マイワシの冷凍時に脱水 シートを使用する上, 過酸化物価の上昇が抑制されるこ とが明らかになっている5).しかし, 冷凍マイワシを実
際に調理した際の官能評価については検討が不十分である. 本研究では，マイワシを家庭用冷凍庫で 4 週間まで保 存後, 煮付け, 塩焼き, ソテーおよびから揚げの 4 種の 調理を行い，五段階評価法および二点識別法により官能 検查を行ない, 脱水シートの効果について検討した.

\section{1. 実験方法 \\ (1) 材 料}

実験に供したマイワシ（Sardinopus melanosticus） は, 1 匹120〜140gのあのを鮮魚店から購入した. マイ ワシは内葴を除去後, 1 匹ずつ脱水シート（ピチット、昭 和電エプラスチックプロダクッ）またはポリエチレン製 フリーザーバッグで包装し, 家庭用冷蔵庫のフリーザー $\left(-20^{\circ} \mathrm{C}\right)$ で保存した. 1,2 または 4 週間保存後, 包装し たまま水道水に清けて解凍し，ただちに調理害験に使用 した. 解涷した際, 魚の重量およびドリップ量を測定した.

(2) 調理法

塩焼きは，魚の重量に対して，1\%の食塩を振り，電気 オーブンを使用して $180^{\circ} \mathrm{C} て ゙ 6$ 分間焙焼した. 煮付け は, 魚を 4 つにぶつ切りにし, 魚の重量に対して $1 / 2$ 相 当量の 5 倍に希釈したしょう油を入れ，中火で 8 分間著 付けた. ソテーは, 魚を 4 つにぶつ切りにして $1 \%$ の振 り塩の後,フライパンを使用して市販サラダ油（なたね および大豆の混合油，日清製油）を魚重量の $5 \%$ ひいて から 8 分加熱した．加ら揚げは，魚を 4 つにぶつ切りに して 1\%の振り塩の後, ソテーと同じ市販サラダ油を使 用して $180^{\circ} \mathrm{C}$ で 4 分間揚げた.

(3) 官能検查

調理直後に, 家政学専攻の短期大学生約 20 名をパネ ルとして, 脱水シート区と対照区（フリーザーバッグ） の両者について五段階評価法および良い方を選択する二 点識別法で, 4 項目 (生具み, 水っぱさ, 味, 総合) につ いて官能検查を行った. 五段階評価法においては, 平均 点土SE を算出し Student $\mathrm{t}$ テストにより，後者につい ては両者の差を $\chi^{2}$ 検定により有意差検定を行い, $\mathrm{p}<$ 0.05 の場合を有意差ありとした。

\section{2. 結果およひ考察}

(1) 冷凍保存中のマイワシの重量変化とドリップ量

脱水シートで包装したまま保存すると，魚の重量は 1 週間後には $96 \%$ に減少した。これは生鮮マイワシを脱 水シートで包装してから冷凍庫に入れたため，凍結が完 了するまでに水分が失われたもの之思われる，一方，対 照区では保存後む解凍前にはほとんど重量変化がなかっ

* 東北大学大学院農学研究科（广981-8555 仙台市青葉区堤通雨宮町 1-1） 
表 14 週間冷凍保存したマイワシを調理した 4 種類の料理の官能評価

\begin{tabular}{|c|c|c|c|c|c|c|}
\hline \multirow{2}{*}{ 調理法 } & \multirow{2}{*}{ パネル } & \multirow{2}{*}{ 項目 } & \multirow{2}{*}{ 試験区 } & \multicolumn{2}{|c|}{ 五段階評価法 ${ }^{\mathbf{a}}$} & \multirow{2}{*}{$\begin{array}{l}\text { 二点識別法 } \\
\text { パネル選択数 }\end{array}$} \\
\hline & & & & 平均得点土 $\mathrm{SE}$ & $\mathrm{t}$ 值 & \\
\hline \multirow{8}{*}{ 㩔付け } & \multirow{8}{*}{25 名 } & \multirow{2}{*}{ 生臭み } & 脱水シート区 & $2.72 \pm 0.83$ & \multirow{2}{*}{$4.23^{* *}$} & \\
\hline & & & 対照区 & $1.76 \pm 0.76$ & & \\
\hline & & \multirow{2}{*}{ 水っぽさ } & 脱水シート区 & $2.84 \pm 0.92$ & \multirow{2}{*}{$3.27^{* *}$} & 19 \\
\hline & & & 対照区 & $2.12 \pm 0.52$ & & \\
\hline & & \multirow{2}{*}{ 味 } & 脱水シート区 & $3.04 \pm 0.92$ & \multirow{2}{*}{$4.32^{* *}$} & 20 \\
\hline & & & 対照区 & $2.38 \pm 0.72$ & & \\
\hline & & \multirow{2}{*}{ 総合評価 } & 脱水シート区 & $3.26 \pm 0.97$ & \multirow[t]{2}{*}{$5.77^{* *}$} & $21)_{* *}$ \\
\hline & & & 対照区 & $2.26 \pm 0.73$ & & \\
\hline \multirow{8}{*}{ 塩焼き } & \multirow{8}{*}{25 名 } & \multirow{2}{*}{ 生臭み } & 脱水シート区 & $2.72 \pm 0.83$ & \multirow{2}{*}{$4.23^{* *}$} & \\
\hline & & & 対照区 & $1.76 \pm 0.76$ & & \\
\hline & & \multirow{2}{*}{ 水っぽさ } & 脱水シート区 & $2.84 \pm 0.93$ & \multirow{2}{*}{$3.27^{* *}$} & 19 \\
\hline & & & 対照区 & $2.12 \pm 0.52$ & & \\
\hline & & \multirow{2}{*}{ 味 } & 脱水シート区 & $3.04 \pm 0.92$ & \multirow[t]{2}{*}{$4.32^{* *}$} & 20 \\
\hline & & & 対照区 & $2.28 \pm 0.72$ & & \\
\hline & & \multirow{2}{*}{ 総合評価 } & 脱水シート区 & $3.16 \pm 0.97$ & \multirow{2}{*}{$5.78^{* *}$} & $21) * *$ \\
\hline & & & 対照区 & $2.16 \pm 0.73$ & & \\
\hline \multirow{8}{*}{ ソテー } & \multirow{8}{*}{21 名 } & \multirow{2}{*}{ 生臭み } & 脱水シート区 & $3.52 \pm 1.14$ & $3.39^{* *}$ & 17) $* *$ \\
\hline & & & 対照区 & $2.43 \pm 1.05$ & & \\
\hline & & 水っぱさ & 脱水シート区 & $3.00 \pm 0.87$ & 1.43 & 13 \\
\hline & & 小的 & 対照区 & $2.67 \pm 0.64$ & & 8 \\
\hline & & 味 & 脱水シート区 & $3.57 \pm 0.66$ & $2.37^{*}$ & $15) *$ \\
\hline & & & 対照区 & $2.81 \pm 0.91$ & & \\
\hline & & & 脱水シート区 & $3.62 \pm 0.65$ & $2.79^{* *}$ & $16)_{* *}$ \\
\hline & & 総台評価 & 対照区 & $2.81 \pm 0.85$ & 2.10 & \\
\hline & & 生臭み & 脱水シート区 & $3.17 \pm 0.83$ & 1.24 & $14)$ * \\
\hline & & 生䏍为 & 対照区 & $2.83 \pm 0.83$ & & \\
\hline & & 水っぽさ & 脱水シート区 & $3.39 \pm 0.49$ & $2.69^{* *}$ & $15) * *$ \\
\hline 加ら揚げ & & 小の比 & 対照区 & $2.89 \pm 0.66$ & & \\
\hline から揚げ & 18 名 & 味 & 脱水シート区 & $3.61 \pm 0.68$ & 1.09 & 13)* \\
\hline & & 林 & 対照区 & $3.33 \pm 0.67$ & & \\
\hline & & 総合評価 & 脱水シート区 & $3.26 \pm 0.60$ & $2.21^{*}$ & $14) *$ \\
\hline & & & 対照区 & $2.26 \pm 0.66$ & & \\
\hline
\end{tabular}

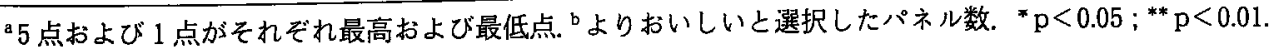

たが, 解凍後は保存期間が長くなると重量が減少した。 これは, 対照区でのドリップ量の堌加と対応し，4 週間 保存後のドリップ量は, 対照区では保存前の魚重量に対 して $5.3 \%$ であったのに対し, 脱水シート区では $2.0 \%$ と 半分以下だった.

（2）調理した冷凍マイワシの官能評価
詳細なデータは示していないが，マイワシを $1,2,4$ 週間 冷凍保存後, 者付けた際の官能栻験の結果，保存期間の延長 とともに脱水シート区が対照区より有意に高い評価を得た。 そこで，煮付け以外の 3 種の調理法についても，4週間 冷凍保存した試料を調理，官能検查に使用することにした.

表 1 に示したように，煮付けおよび塩焼きにおいて 
は，五段階評価法においてすべての項目で脱水シート区 が顕著に高い評価（p<0.01）を得た，二点識別法でむ， すべて 4 項目に亘って脱水シート区が良好と選択され た.ソテーにおいては, “生臭み”, “味”および“総合” で脱水シート区が両評価法で有意に高い評価を得た。一 方, “水っぽさ”では, 脱水シート区の方が高い点数を得 たが，有意差はなかった，から揚げについては，五段階 評価法において“水っぽさ”と“総合”で脱水シート区 が有意に評価が高かったが，“生臬み”上“味”では有意 差はなかった。一方，二点識別法では，すべての項目で 脱水シート区が有意に良いと評価された。

これらの官能検查の結果を考察すると，4 週間冷凍保 存したマイワシを煮付け，塩焼き，ソテーあるいはから 揚げに調理した場合, 脱水シート使用による有意な食味 の向上が観察された．なかでも，煮付けおよび塩焼きは すべての項目で有意差があり，これは素材の風味がその まま反映しやすい調理法のため，差が認識されやすかっ たと考えられる、それに比較して，ソテーでは“水っぽ さ”，から揚げでは“生臭み”で有意差がなく，これらの 調理法では, 油脂を使用して高温で調理するため, 水分 やにおい物質が調理中に食品から失われると同時に強い 加熱香気が加わるため, 素材の風味が反映しにくかった あのと推定される.

前報 ${ }^{2)}$ では冷凍畜肉類の官能評価に対する脱水シート の効果を調べたが，その際には脱水シートを使用すると 官能評価は高い傾向は認められたが, 統計的な有意差が
出た項目は極めて限られ, 今回のマイワシの場合の方が 効果が明確だった，冷凍マイワシの保存中，脱水シート を使用すると脂質過酸化が抑えられることはすでに観察 した5)、マイワシで脱水シートの効果がより顕著だった のは, 脱水シートによりマイワシの表層から軽度に脱水 されることにより皮の部分の水結晶の成長が抑えられ， 組織破壊が抑制されたことが原因と考えられる，そのた め，皮に存在するリポキシゲナーゼ，ヒドロペルオキシ ドリアーゼかの作用が進みにくくなり，アルデヒドに起 因する魚臭の発生が抑制されたすの之推定される.

\section{3. 要 約}

ポリエチレン袋あるいは脱水シートで包装したマイワ シを家庭用冷凍庫で 4 週間保存し，その後煮付け，塩焼 き,ソテーおよびから揚げの調理をして官能検査を行っ た. その結果， 4 種のすべての調理法で脱水シートを使 用したあのが対照区より有意に高い評価を得た。

\section{文献}

1）織田修輝，食科工：44，926（1997）。

2）保井明子, 高島櫓子, 藤本健四郎, 日本調理科学 会誌, 29, 207 (1996).

3) Mohri, S., Tokuori, K., Endo, Y. and Fujimoto K., Fisheries Sci., 65, 270 (1999).

4) Mohri, S., Cho, S.-Y., Endo, Y. and Fujimoto K., J. Agric. Food Chem., 40, 573 (1992).

5）瀬戸美江, 藤本健四郎, 調理科学, 27, 2 (1994). (平成 14 年 1 月 5 日受付, 平成 14 年 4 月 21 日受理) 